MS13-P08

\section{Crystallographic characteristics of the siliceous lithic material from the deposit and the outcrops to explore the supply sources of Mesolithic groups from the Los Canes cave}

María de Uribe-Zorita ${ }^{1}$, Celia Marcos

1. Departamento de Geología; Universidad de Oviedo, Oviedo, Spain email: mariatiska96@gmail.com

The crystallographic and mineralogical characterization (macroscopic and microscopic) of the Mesolithic lithic raw materials allows to analyze the establishment of mobility and exchange patterns; identify the adequacy between the technical processes of manufacturing and the selected raw material and find out the development of strategies in the acquisition and selection of lithic resources.

Only a few attempts have been undertaken to use the crystallinity of flint or the moganite content of chert for alternative or additional characterization and discrimination of lithic material (Bustillo et al., 2009; Graetsch and Grünberg, 2009).

In order to relate the lithic materials of the Los Canes cave (eastern Asturias, Spain) with possible supply outcrops a crystallographic study has been made with X-ray powder diffraction in order to identify and quantify the crystalline phases and obtain crystallographic data (crystal size, lattice strain, etc.) of them for comparision. Analyses with the scanning electron microscope + EDX and Infrared spectra were also considered.

Los Canes cave, with indications of Mesolithic human activity, in the interior part of the Asturian region on the northeast edge of the Hesperian chain that constitutes the substratum of the Iberian Peninsula. This region is mainly constituted by Palaeozoic rocks (with ages ranging from the Middle Cambrian to the Upper Carboniferous (Alonso and Pulgar, 1995) elevated by the Alpine orogeny, which created a typical Germanic geomorphology. Flint does not occur very frequently in this region, but some of them, of Lower Carboniferous age, can be found in the Picos de Europa region. The tectonic movements related to the Variscan orogeny displaced and eroded these materials towards the south. The Alpine orogeny of the Tertiary era and the Quaternary glacial and fluvial erosion configured the current relief, relocating part of the flints (Marquínez and Adrados, 2000). Additionally, at both edges of the region some accumulations of flint can be found in some small remains of Mesozoic basins.

The Mesolithic main materials knapped in the Los Canes cave were grey flint, black flint, radiolarite, Pendueles chert, Cretaceous flint, quartzite and quartz; quartzite is the dominant raw material in weight, except in the Late Mesolithic phase of the site, dated to the sixth millennium cal $\mathrm{BC}$, where this raw material drops sharply and flint reaches $63.3 \%$ (Arias et al., 2009). These varieties were recognized in the field, in different outcrops.
References:

Alonso, J. L. and Pulgar, J. A., 1995. La estructura de la Zona Cantábrica, in C. Aramburu and F. Bastida (eds.), Geología de Asturias, 103-12. Gijón, Trea

Arias Cabal, P., Fernández, P., Marcos, C. \& Rodríguez, I., 2009. The elusive flint: raw materials and lithic technology in the Mesolithic of eastern Asturias, Spain. In: Mesolithic Horizons (Woodman, P. \& Schulting, R., Eds.), Oxbow Books, Oxford.

Bustillo, M. A., plus eight authors, 2009. Is the macroscopic classification of flint useful? A petroarchaeological analysis and characterization of flint raw materials from the Iberian Neolithic mine of Casa Montero. Archaeometry, 51, 175-96.

Graetsch, H. A., and Grünberg, J. M., 2009. Defect microstructure of chalcedony in flint and chert. Annual Meeting of the Mineralogical Society of Great Britain and Ireland in Edinburgh.

Marquinez, J. and Adrados, L., 2000. La Geología y el Relieve de los Picos de Europa. Naturalia Cantabriacae, 1, 3-19.

Keywords: Flint, Los Canes, Mesolithic 